\title{
Digestive Enzymes in the Crayfish Cherax albidus: Polymorphism and Partial Characterization
}

\author{
Elena Coccia, Ettore Varricchio, and Marina Paolucci \\ Department of Biological and Environmental Sciences, Faculty of Sciences, University of Sannio, Via Port'Arsa 11, \\ 82100 Benevento, Italy \\ Correspondence should be addressed to Marina Paolucci, paolucci@unisannio.it
}

Received 27 December 2010; Revised 2 March 2011; Accepted 24 March 2011

Academic Editor: Iain J. McGaw

Copyright (๑) 2011 Elena Coccia et al. This is an open access article distributed under the Creative Commons Attribution License, which permits unrestricted use, distribution, and reproduction in any medium, provided the original work is properly cited.

We will deal with the partial characterization and the activity of the following digestive enzymes: amylase, pectinase, alginase, lipase, and protease present in the digestive tract of juvenile freshwater crayfish Cherax albidus. Gastric juices, the hepatopancreas, and the intestine were sampled for enzyme analysis. Among carbohydratases, amylase activity was the highest. It was significantly higher in the intestine than in the gastric juice and hepatopancreas. Lipase activity was significantly higher in the hepatopancreas and the intestine compared to the gastric juice. Both alkaline and acid proteases were found. Alkaline proteases were characterized by employing specific protease inhibitors. Both trypsin and chymotrypsin activity was detected. The majority of alkaline protease activity was ascribable to trypsin. Several isoforms of digestive enzymes were identified by gel electrophoresis. This work provides basic information to study the digestive abilities of crayfish.

\section{Introduction}

In crustaceans, the assimilation of nutrients depends on their complex digestive machinery. In fact, their ability to obtain nutrients from a broad range of food source derives largely from physiological processes occurring in the digestive tract including the profile and activity of the digestive enzymes that are present [1]. Different crustacean species exhibit a particular array of digestive enzymes that reflects their different feeding habits and habitats [2]. Crayfish of the genus Cherax are considered detritivorous/omnivorous consuming a range of plant, animal, algal, and detrital material [3]. Their digestive enzymes are capable of hydrolyzing the wide variety of substrates that they encounter in their natural diet reflecting their capacity to adapt to a varied diet [4]. It is well documented that Cherax quadricarinatus digest plant-based ingredients more efficiently than animal-based ones $[5,6]$. Digestive enzyme activity has been reported in some species of Cherax genus [4, 7-9]. Among proteases, both serine proteases (trypsinand chymotrypsin-like enzymes) and cysteine proteases have been identified although the former were predominant [4]. Carbohydratases found in the Cherax species included amylases, cellulases, endo- $\beta 1,4$-glucanases, $\beta$-glucosidases, laminarinases, lichenases, xylanases, endochitinases, and $\mathrm{N}$ acetyl- $\beta$-D-glucosaminidases $[4,7,9]$. Lipase activities have been reported in Cherax quadricarinatus $[7,8]$.

Due to its importance in aquaculture [10], the freshwater crayfish Cherax spp. has been successfully introduced to Europe [11]. However, one of the problems which has prevented the species from being successfully bred in captivity is the lack of research on their digestive functions which prevents us from formulating an adequate diet for them. In Cherax quadricarinatus the digestive enzyme secretion is modified by diet, for example, by the presence of animalor plant-derived ingredients $[12,13]$. Protease, amylase, and cellulase activities have been found to be positively correlated with dietary protein levels [14] and negatively correlated with high cellulose levels [15]. Thus, digestive enzyme responsiveness to feeding might clarify nutritional requirements and consequently, physiological adaptation to formulated diets.

In this light, we have undertaken a study in order to determine the presence and the activity of amylase, pectinase, alginase, and agarase among carbohydratases, lipases, and proteases within the digestive tract of juvenile freshwater crayfish Cherax albidus fed a diet formulated to contain equal 
amounts of carbohydrates and proteins and a low percentage of lipids. Such a formulation seems adequate for juvenile Cherax on the basis of the current literature $[16,17]$.

This study provides basic information on the digestive enzymes present in the digestive tract allowing the indirect identification of the main regions where digestion takes place and to what extent the diet composition modifies the digestive capability. Another goal of this study was to determine the isoforms of each digestive enzyme, providing a general description of the isoenzyme electrophoretic patterns along the digestive tract.

\section{Materials and Methods}

2.1. Experimental Animals. Juvenile crayfish Cherax albidus of $0.5 \pm 0.2$ gr. live weight were obtained from the "Pilot Aquaculture Laboratory for Cherax spp. intensive farming", located in Siculiana (Siciliy, Italy) and transferred to our laboratory at the Department of Biological and Environmental Sciences (Benevento). The crayfish were imported from Mulataga Aquaculture (Perth, Western Australia, P.O. Box 343 Gosnells 6110), as Cherax albidus, and resulted, according to the European Community Law, in good health and disease-free (Health Certificate n. 4436915).

2.2. Installation. The recirculation system consisted of rectangular, glass tanks of $20 \times 20 \times 20 \mathrm{~cm}$. Active carbon filters were installed to eliminate chlorine from the city water. Each tank hosted one animal (the animals were singularly housed). A total of 20 animals were used in this experiment. The system was held under LD 12:12 photoperiod. Temperature and $\mathrm{pH}$ (pHmeter GLP 21 Crison) were checked daily. Dissolved oxygen, total ammonia nitrogen, nitrite nitrogen, nitrate nitrogen, phosphorus, phosphate, total chlorine, and hardness $\left(\mathrm{CaCO}_{3}\right)$ were measured twice a week with a Hanna Instruments Photometer C200. Diet proximal analysis was carried out according to the methods of the AOAC [18] (Table 1). The ingredients were lyophilized and then added to water and stirred. Mixtures were then extruded at room temperature to improve the process of material blending. The achieved "spaghetti" were cut in the form of cylinders: "pellets", of about $1 \mathrm{~cm}$ length $\times 0.1 \mathrm{~cm}$ diameter and dry for $24 \mathrm{~h}$ under a hood. Animals were fed every day between 8:00 and 9:00 am for 12 weeks. Untouched food, if any, was removed within 4 hours after the feeding. The amount of food administered was $5 \%$ of the total body weight and was adjusted every two weeks based on the weight of the animal. All animals were weighed once every two weeks and at the conclusion of the experiment (initial weight $=0.5 \pm 0.2 \mathrm{gr}$.; final weight $=2.1 \pm 0.3$ gr. .

2.3. Enzymatic Activity. Animals were sacrificed $12 \mathrm{hrs}$ after the last feeding. Gastric juice was obtained through the oral cavity into a disposable plastic pipette. The $\mathrm{pH}$ was determined (mean value was $7.5 \pm 0.2$ ), and the gastric juice was transferred into microtubes and centrifuged for $10 \mathrm{~min}$ at $10.000 \times \mathrm{g}$ at $4^{\circ} \mathrm{C}$. The supernatant was immediately used for the enzymatic analysis. The hepatopancreas and
TABle 1: Proximal composition of the experimental diet (dry matter). Values are expressed as mean \pm SEM. Analysis were carried out in duplicate on 4 different batches $(n=4)$.

\begin{tabular}{lc}
\hline Composition & Diet $(100 \mathrm{~g})$ \\
\hline Total fat $(\mathrm{g})$ & $7.40 \pm 0.14$ \\
Saturated fat $(\mathrm{g})$ & $2.67 \pm 0.02$ \\
Unsaturated fat $(\mathrm{g})$ & $4.73 \pm 0.02$ \\
Cholesterol (mg) & $128.53 \pm 0.51$ \\
Sodium (mg) & $13.76 \pm 1.5$ \\
Total Carbohydrates (g) & $41.38 \pm 0.32$ \\
Fibers (g) & $3.53 \pm 0.07$ \\
Sugars (mono-disaccharides) (g) & $3.98 \pm 0.02$ \\
Proteins (g) & $39.37 \pm 0.31$ \\
Calcium (mg) & $325.36 \pm 5.01$ \\
Iron (mg) & $11.08 \pm 0.55$ \\
\hline
\end{tabular}

the intestine of each animal were removed, weighed, and homogenized separately with four volumes of buffer Tris$\mathrm{HCl}, 50 \mathrm{mM}, \mathrm{pH}$ 7.0. Homogenates were centrifuged for $15 \mathrm{~min}$ at $23.000 \times \mathrm{g}$ at $4^{\circ} \mathrm{C}$. The supernatants containing soluble proteins (enzyme extract) were immediately used for the enzymatic analysis. Total proteins were evaluated with the Bradford method using bovine serum albumin (BSA) as standard. Due to the small sample volume, the gastric juice, hepatopancreas and intestine extracts of two-three crayfish were pooled.

Amylase, pectinase and alginase activities were determined according to López-López et al. [12] with minor modifications. Briefly, a $1 \%$ solution of starch, pectin, and alginate were made separately in Tris- $\mathrm{HCl}$ buffer $50 \mathrm{mM}$, pH 6.5 , and were used as substrate to measure the production of reducing sugars resulting from the hydrolysis of the correspondent substrate. A mixture containing $495 \mu \mathrm{L}$ of Tris$\mathrm{HCl}$ buffer, $500 \mu \mathrm{L}$ of substrate solution, and $5 \mu \mathrm{L}$ of enzyme extract was incubated for $10 \mathrm{~min}$ at $25^{\circ} \mathrm{C}$. Afterwords, $1.5 \mathrm{~mL}$ of dinitrosalicylic acid (DNS) reagent (1\% DNS in $0.4 \mathrm{M}$ $\mathrm{NaOH} 30 \% \mathrm{Na} / \mathrm{K}$ tartrate solution) was added to the mixture and boiled for $15 \mathrm{~min}$. The volume was adjusted to $10 \mathrm{~mL}$ with distilled water and the coloured solution was read at $550 \mathrm{~nm}$ with a Spectrophotometer Thermo Spectronic Biomate 3 UV VIS.

Analysis of lipase activity was performed according to López-López et al. [8] using $\alpha$-naphthyl caprylate as substrate. The assay mixture contained: $100 \mu \mathrm{L}$ of $100 \mathrm{mM}$ sodium taurocholate, $1875 \mu \mathrm{L}$ of $50 \mathrm{mM}$ Tris- $\mathrm{HCl} \mathrm{pH} 7.5$, $5 \mu \mathrm{L}$ of enzyme extract, and $20 \mu \mathrm{L}$ of $200 \mathrm{mM} \alpha$-naphthyl caprylate dissolved in dimethyl sulfoxide (DMSO). The mixture was incubated for $30 \mathrm{~min}$ at $25^{\circ} \mathrm{C}$, then $20 \mu \mathrm{L}$ of $100 \mathrm{mM}$ Fast Blue (in DMSO) were added. The reaction was stopped with $200 \mu \mathrm{L}$ of $0.72 \mathrm{~N}$ TCA. The mixture was centrifuged for $5 \mathrm{~min}$ at $14.000 \times \mathrm{g}$ to remove the precipitated proteins. The volume was adjusted to $5 \mathrm{~mL}$ with $1: 1 \mathrm{v} / \mathrm{v}$ ethanol/ethyl acetate solution and absorbance was recorded at $540 \mathrm{~nm}$.

Alkaline protease activity of the extracts was assayed according to Fernández-Gimenez et al. [19] using 1\% 
azocasein in $50 \mathrm{mM}$ Tris- $\mathrm{HCl}$ buffer, $\mathrm{pH} 7.5$, as substrate. Five $\mu \mathrm{L}$ of enzyme extract was mixed with $0.5 \mathrm{~mL}$ of Tris$\mathrm{HCl}$ buffer and $0.5 \mathrm{~mL}$ of substrate solution. The mixture was incubated for $10 \mathrm{~min}$ at $25^{\circ} \mathrm{C}$, and the proteolysis was stopped by the addition of $0.5 \mathrm{~mL}$ of $20 \%$ trichloroacetic acid (TCA). Unhydrolyzed azocasein precipitated by TCA was centrifuged for $5 \mathrm{~min}$ at $14.000 \times \mathrm{g}$. The amount of hydrolyzed azocasein was measured at $366 \mathrm{~nm}$.

Acid protease activity was evaluated according to the method described by Navarrete del Toro et al. [20] using a solution of $0.5 \%(\mathrm{w} / \mathrm{v})$ bovine hemoglobin in $0.1 \mathrm{M}$ glycine/ $\mathrm{HCl}$ buffer, $\mathrm{pH} 2.0$, as substrate. One milliliter of the substrate solution was mixed with $5 \mu \mathrm{L}$ of enzyme extract and incubated for $10 \mathrm{~min}$ at $25^{\circ} \mathrm{C}$. The reaction was stopped by adding $500 \mu \mathrm{L}$ of $20 \%$ TCA and cooling on ice for $10 \mathrm{~min}$. The undigested substrate precipitated was separated by centrifugation for $5 \mathrm{~min}$ at $10.000 \times \mathrm{g}$. The absorbance of the supernatant was measured spectrophotometrically at $280 \mathrm{~nm}$. All the enzymatic assays were conducted at the optimum $\mathrm{pH}$, temperature, and incubation time that have been investigated in previous experiments. Such conditions refer to in vitro assays. For every assay, a control was prepared by substituting the enzyme extract with the correspondent buffer. The enzymatic activity was expressed as units/mg protein $\left(\mathrm{U} \mathrm{mg}^{-1}\right)$. The assays were carried out in duplicate.

In order to evaluate the major classes of the alkaline proteolytic enzymes in the digestive tract, enzyme samples were incubated with specific protease inhibitors according to Fernández-Gimenez et al. [19]. Samples were separately added to inhibitors in a ratio of $1: 1$ and incubated at $25^{\circ} \mathrm{C}$ for $60 \mathrm{~min}$. $N \alpha$ - $p$-tosyl-lysine chloromethyl ketone (TLCK, $10 \mathrm{mM}$ in $1 \mathrm{mM} \mathrm{HCl} \mathrm{pH} \mathrm{3.0)} \mathrm{and} N$-tosyl- $L$-phenylalanine chloromethyl ketone (TPCK, $5 \mathrm{mM}$ in $\mathrm{MeOH}$ ) were used as specific inhibitors of trypsin and chymotrypsin, respectively; soybean trypsin inhibitor (SBTI, $250 \mathrm{mM}$ in distilled water) and phenylmethylsulfonyl fluoride (PMSF, $100 \mathrm{mM}$ in 2propanol) were used as serine protease inhibitors; pepstatin A (1 mM in DMSO) was used to inhibit aspartic proteases. Distilled water replaced inhibitors in the controls. Subsequently, $0.5 \mathrm{~mL}$ of a substrate solution containing $1 \%$ azocasein in $50 \mathrm{mM}$ Tris- $\mathrm{HCl}, \mathrm{pH} 7.5$, was added to the treated samples. The reactions were stopped $10 \mathrm{~min}$ later by adding $0.5 \mathrm{~mL}$ of $20 \%$ TCA and the mixtures were centrifuged for $5 \mathrm{~min}$ at $14.000 \times \mathrm{g}$. The absorbance of the supernatants was measured at $366 \mathrm{~nm}$. Residual activities were reported as percentage of inhibition. Activity measured in the absence of inhibitor was considered as $100 \%$. All reagents were from Sigma (Sigma-Aldrich, St. Louis, Mo, USA), sodium alginate was supplied by Lianyungang Zhongda Seaweed Industrial Co., Ltd. (China).

2.4. Effect of $p H$, Temperature and Incubation Time on Digestive Enzyme Activities. The best enzymatic assay conditions were investigated in order to evaluate the effect of $\mathrm{pH}$, temperature and incubation time on enzymatic activity [21, 22]. The $\mathrm{pH}$ tolerance profiles of digestive enzymes were determined by adjusting the $\mathrm{pH}$ of substrate buffers used in the assays. For amylase, the substrate buffers used were $0.1 \mathrm{M}$ citric acid/0.2 $\mathrm{M} \mathrm{Na}_{2} \mathrm{HPO}_{4}$ for the $\mathrm{pH}$ values 4.0, 5.0, 5.5, 6.0, and $0.05 \mathrm{M}$ Tris- $\mathrm{HCl}$ for the $\mathrm{pH}$ values $6.5,7.0,7.5,8.0,8.5$, and 9.0. For the lipase, the substrate buffer used was $0.05 \mathrm{M}$ Tris- $\mathrm{HCl}$ for the $\mathrm{pH}$ values $6.5,7.0,7.5,8.0,8.5,9.0,9.5$, and 10.0. For the alkaline protease, the substrate buffer used was $0.05 \mathrm{M}$ Tris- $\mathrm{HCl}$ for the $\mathrm{pH}$ values 6.5, 7.0, 7.5, 8.0, 8.5, 9.0, 9.5 , and 10.0. For the acid protease, the substrate buffer used was $0.1 \mathrm{M}$ glycine- $\mathrm{HCl}$ for the $\mathrm{pH}$ values 2.0, 2.5, 3.0, 3.5, 4.0, 4.5 , and 5.0.

The temperature tolerance profiles of digestive enzymes were determined by assaying enzyme activities at $4,10,15$, $20,25,30,37,40,50,60$, and $70^{\circ} \mathrm{C}$.

The best incubation time of digestive enzymes were determined by assaying enzyme activities at $0,5,10,15,20$, $30,45,60$, and $90 \mathrm{~min}$.

2.5. SDS-PAGE and Substrate-SDS-PAGE (Zymogram Analysis). Samples analyzed for enzymatic activity underwent zymogram analysis. Proteins were separated by $12 \%$ SDSPAGE. Samples were neither boiled nor treated with $\beta$-mercaptoethanol before loading into the gel and were run at $4^{\circ} \mathrm{C}$ at maximum $15 \mathrm{~mA}$ per gel. Molecular weight markers (Invitrogen) without reducing agents were employed as standards. After electrophoresis, gels were stained with $0.25 \%$ Comassie Brillant Blue R-250 in 50\% methanol and 10\% acetic acid. Substrate-SDS-PAGE for amylase was performed according to Perera et al. [21] with minor modifications. Proteins were separated by $12 \%$ SDS-PAGE. After electrophoresis, gels were immersed in a $1 \%$ starch solution (in Tris- $\mathrm{HCl}$ buffer $50 \mathrm{mM}, \mathrm{pH}$ 6.5) for $60 \mathrm{~min}$ and then stained with $10 \%$ iodine/KI solution. Substrate-SDS-PAGE for lipase was performed according to López-López et al. [8] with slight modifications. The separation of proteins was performed under native conditions on $12 \%$ polyacrylamide gel. After electrophoresis, gels were immersed into a solution of $50 \mathrm{mM}$ Tris- $\mathrm{HCl} \mathrm{pH}$ 8.0, $100 \mathrm{mM} \alpha$-naphthyl caprylate, and $100 \mathrm{mM}$ fast blue and incubated until activity bands were revealed. In order to determine the composition and the molecular mass of proteases in the digestive tract, a substrate-SDSPAGE was carried out according to Perera et al. [21] with some modifications. Solutions of TLCK, TPCK, SBTI, PMSF and pepstatin A were added separately to the enzyme samples in a ratio of 1:2 (inhibitor: enzyme extract) and incubated at $25^{\circ} \mathrm{C}$ for $60 \mathrm{~min}$. Distilled water replaced inhibitors in the controls. Subsequently, the treated samples were subjected to SDS-PAGE following the same conditions described previously. After electrophoresis, gels were submerged in $1 \%$ azocasein solution for $30 \mathrm{~min}$ at $4^{\circ} \mathrm{C}$ and then the temperature was raised to $25^{\circ} \mathrm{C}$ for an additional $90 \mathrm{~min}$. Thereafter, gels were thoroughly washed with distilled water, fixed and stained with 0.25\% Comassie Brillant Blue R-250 solution and, finally, distained. Bands detected in the presence or absence of inhibitors were compared. Zymograms with and without inhibitors were run and analyzed for the presence or absence of activity bands.

2.6. Statistical Analysis. Data were analyzed by one-way analysis of variance (ANOVA), and any significant difference 


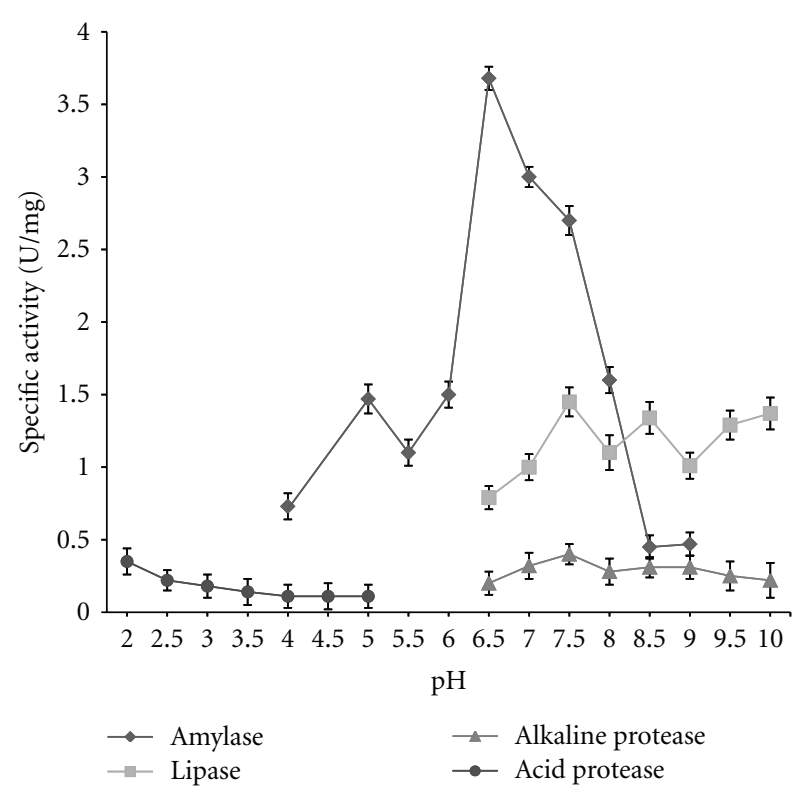

Figure 1: Effect of $\mathrm{pH}$ on the activity of amylase, lipase, alkaline, and acid proteases in the hepatopancreas of crayfish Cherax albidus juveniles. Gastric juice and intestine gave similar results. Values are reported as means \pm SEM. Assays were performed on three samples in duplicate.

was determined at.05 level by Tukey's test. The analysis were carried out with the Statistica version 7.0 statistical package (Statsoft Inc., Tulsa, Okla, USA). Data are expressed as Mean \pm SEM.

\section{Results}

3.1. Water Parameters. Water parameters were detected for the duration of the growth experiment. Temperature ranged between $23^{\circ} \mathrm{C}$ and $25^{\circ} \mathrm{C}$, pH between 7.9 and 8.4, dissolved oxygen between 3-4 mg/L, total ammonia nitrogen between 0 and $0.35 \mathrm{mg} / \mathrm{L}$, nitrite nitrogen between 0.02 and $0.07 \mathrm{mg} / \mathrm{L}$, nitrate nitrogen between 7.5 and $11.3 \mathrm{mg} / \mathrm{L}$, total chlorine between $0.04-0.20 \mathrm{mg} / \mathrm{L}$, phosphate between $0.33-1.7 \mathrm{mg} / \mathrm{L}$, and phosphorus between $0.2-2.2 \mathrm{mg} / \mathrm{L}$.

3.2. Effect of $p H$ on Digestive Enzyme Profiles. The effect of $\mathrm{pH}$ on the activity of amylase, lipase, alkaline, and acid proteases in the hepatopancreas of crayfish is reported in Figure 1. Amylase showed a one-peak pattern at $\mathrm{pH}$ 6.5. Lipase and alkaline protease showed the highest activity at $\mathrm{pH} 7.5$ although it was high from $\mathrm{pH} 7.0$ to $\mathrm{pH}$ 10.0. Acid protease showed an optimum at $\mathrm{pH} 2.0$, the specific activity dropping steadily from $\mathrm{pH} 2.5$ to $\mathrm{pH}$ 5.0.

3.3. Effect of Temperature on Digestive Enzyme Profiles. The effect of temperature on the activity of amylase, lipase, alkaline, and acid proteases in the hepatopancreas of crayfish is reported in Figure 2. The optimum temperature for amylase activity was $25^{\circ} \mathrm{C}$. Lipase activity increased steadily

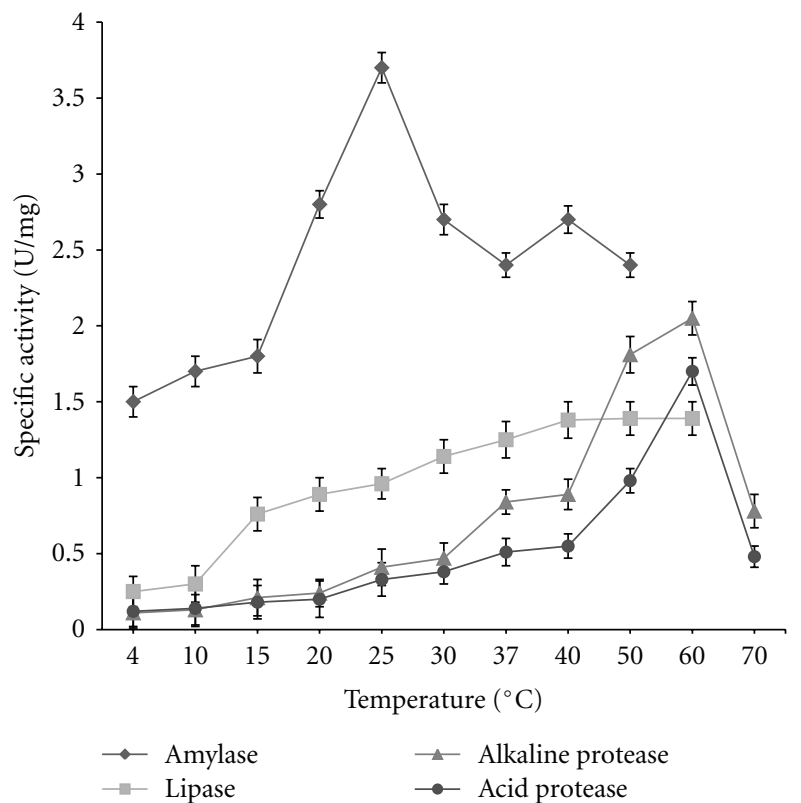

FIGURE 2: Effect of temperature on the activity of amylase, lipase, alkaline, and acid proteases in the hepatopancreas of crayfish Cherax albidus juveniles. Gastric juice and intestine gave similar results. Values are reported as means \pm SEM. Assays were performed on three samples in duplicate.

from $15^{\circ} \mathrm{C}$ to $40^{\circ} \mathrm{C}$, and kept stable up to $60^{\circ} \mathrm{C}$. Both alkaline and acid protease activities were stable from $37^{\circ} \mathrm{C}$ to $70^{\circ} \mathrm{C}$ with an optimum at $60^{\circ} \mathrm{C}$.

3.4. Effect of Incubation Times on Digestive Enzyme Profiles. The effect of incubation times on the activity of amylase, lipase, alkaline, and acid proteases in the hepatopancreas of crayfish is reported in Figure 3. The best incubation time for amylase activity was $10 \mathrm{~min}$. After this time, the specific activity decreased steadily. Lipase activity showed the highest value after $30 \mathrm{~min}$ and kept stable for up to $90 \mathrm{~min}$. Both alkaline and acid proteases were very stable at all tested incubation times. Although the optimum temperature for lipase and alkaline and acid proteases ranged from 40 to $60^{\circ} \mathrm{C}$, the enzymatic assays were carried out at $25^{\circ} \mathrm{C}$, since this is the physiological temperature.

3.5. Enzymatic Activity. Results of enzymatic assays are presented in Figure 4 and Table 2. Enzymatic activity has been expressed as both U/gr tissue and U/mg protein. In both cases, among carbohydratases, amylase activity was the highest. It was significantly higher in the intestine than in the gastric juice and hepatopancreas. Lipase activity was significantly higher in the hepatopancreas and intestine than in gastric juice. Both alkaline and acid proteases were found.

3.6. Effect of Specific Inhibitors on Alkaline Protease Activity. In order to identify the type of alkaline protease activity, inhibitors were employed. In Figure 5, inhibitions are reported with respect to total activity along the digestive 


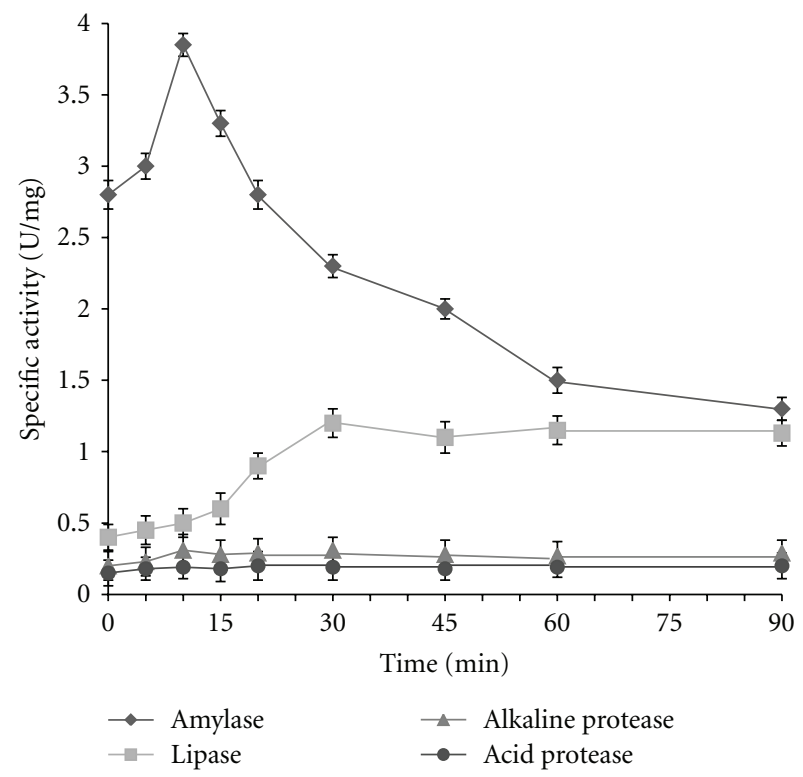

FIGURE 3: Effect of incubation times on the activity of amylase, lipase, alkaline, and acid proteases in the hepatopancreas of crayfish Cherax albidus juveniles. Gastric juice and intestine gave similar results. Values are reported as means \pm SEM. Assays were performed on three samples in duplicate.

TAble 2: Specific activities of amylase, pectinase, alginase, lipase, alkaline protease, and acid protease $\left(\mathrm{Umg}^{-1}\right)$ in the gastric juice (GJ), hepatopancreas (H), and intestine (I) of juvenile Cherax albidus. Data are reported as means \pm SEM. For each enzyme, $n=5$. Asterisks represent statistically significant values $(P<.05)$ along the digestive tract within each enzyme.

\begin{tabular}{lccc}
\hline Specific activity $\left(\mathrm{U} \mathrm{mg}^{-1}\right)$ & GJ & $\mathrm{H}$ & $\mathrm{I}$ \\
\hline Amylase & $3.69 \pm 1.04$ & $5.50 \pm 1.04$ & $10.04 \pm 0.75^{*}$ \\
Pectinase & $0.21 \pm 0.02$ & $0.90 \pm 0.27$ & $1.50 \pm 0.49$ \\
Alginase & $0.02 \pm 0.00$ & $0.08 \pm 0.02$ & $0.30 \pm 0.09$ \\
Lipase & $0.09 \pm 0.03$ & $0.48 \pm 0.09^{*}$ & $0.39 \pm 0.07^{*}$ \\
Alkaline protease & $0.06 \pm 0.02$ & $0.11 \pm 0.02$ & $0.12 \pm 0.00$ \\
Acid protease & $0.10 \pm 0.02$ & $0.27 \pm 0.05$ & $0.20 \pm 0.01$ \\
\hline
\end{tabular}

tract. TLCK, a trypsin inhibitor produced on average of $32 \%$ inhibition in gastric juice and the hepatopancreas, while in the intestine the inhibition was significantly lower, being about $10 \%$. In the whole intestinal tract, the percentage of inhibition by TPCK, an inhibitor of chymotripsin, was on average $20 \%$, the percentage of inhibition by SBTI, a serine protease inhibitor, was on average $54 \%$, the percentage of inhibition by PMSF, a serine protease inhibitor, was on average $16 \%$, and the percentage of inhibition by Pepstatin $\mathrm{A}$, an aspartic protease inhibitor, was on average $5 \%$.

3.7. Enzyme Ratios. The carbohydratase/total protease $(\mathrm{C} / \mathrm{P})$, carbohydratase/lipase $(\mathrm{C} / \mathrm{L})$, and lipase/total protease $(\mathrm{L} / \mathrm{P})$ ratios are reported in Table 3. C/P ratio was significantly higher in gastric juice and in the intestine with respect to the hepatopancreas. The $\mathrm{C} / \mathrm{L}$ ratio was significantly higher
TABLE 3: Carbohydratase/total protease (C/P), carbohydratase/lipase $(\mathrm{C} / \mathrm{L})$, and lipase/total protease $(\mathrm{L} / \mathrm{P})$ ratios in the gastric juice (GJ), hepatopancreas (H), and intestine (I) of juvenile Cherax albidus. Data are reported as means \pm SEM. Asterisks indicate statistically significant differences $(P<.05)$ along the digestive tract within each ratio.

\begin{tabular}{lcrc}
\hline & GJ & H & \multicolumn{1}{c}{ I } \\
\hline $\mathrm{C} / \mathrm{P}$ & $31.2 \pm 2.2^{*}$ & $17.4 \pm 0.8$ & $42.5 \pm 3.3^{*}$ \\
$\mathrm{C} / \mathrm{L}$ & $45.1 \pm 2.7^{*}$ & $20.5 \pm 5.2$ & $39.7 \pm 4.8$ \\
$\mathrm{~L} / \mathrm{P}$ & $0.8 \pm 0.1$ & $1.2 \pm 0.2$ & $1.2 \pm 0.2$ \\
\hline
\end{tabular}

in gastric juice with respect to the hepatopancreas and the intestine. L/P did not statistically vary along the digestive tract.

3.8. Zymogram Analysis. The zymogram of amylase is shown in Figure 6(a). Four bands (MW about 38, 44, 49, and $55 \mathrm{kDa}$ ) with amylolytic activity were present in the gastric juice, hepatopancreas, and intestine. Zymograms for lipases are shown in Figure 6(b). In the gastric juice, two bands were present ( MW about 65 and $70 \mathrm{kDa}$ ), in the hepatopancreas four bands were present (MW about 57, 65, 70, and $118 \mathrm{kDa}$ ) and in the intestine six bands were present (MW about 57, $62,65,70,75$, and $90 \mathrm{kDa})$. Zymograms of proteases are shown in Figure 6(c). Five bands ( MW about 18, 19, 25, 27, and $29 \mathrm{kDa}$ ) were present in the gastric juice, hepatopancreas and intestine. In order to identify the different types of proteases, specific inhibitors were employed, as shown in Figure 6(d). The bands with MW of about 18 and $19 \mathrm{kDa}$ were inhibited by serine protease inhibitors (SBTI and PMSF) and specifically by trypsin inhibitor (TLCK) and, therefore, classified as trypsin-like proteases. The bands with MW of about 25 and $27 \mathrm{kDa}$ were inhibited to some extent by serine protease inhibitors (SBTI and PMSF), but they were not inhibited by either TLCK (trypsin inhibitor) nor TPCK (chymotrypsin inhibitor), and thus, they can be classified as serine proteases but cannot be assigned to either trypsinor chimotrypsin-like protease groups. Finally, the band with an MW of about $29 \mathrm{kDa}$ was inhibited by neither serine nor aspartic protease inhibitors and, therefore, it remains unclassified.

\section{Discussion}

In this study, we examined digestive enzyme activity (amylase, pectinase, alginase, lipases, and proteases) in gastric juice, hepatopancreas and the intestine of juvenile crayfish of Cherax albidus. Generally, the optimum $\mathrm{pH}$ range for amylase, lipase, and protease activity in juvenile Cherax albidus was broadly congruent with that reported in other crustaceans $[2,8,21,23]$.

Amylase activities in the gastric juice and hepatopancreas of Cherax albidus were comparable with the ones reported in Cherax quadricarinatus [12]. In our study, pectinase and alginase were considerably lower than amylase activity. This is not surprising since, as reported in other crustaceans 


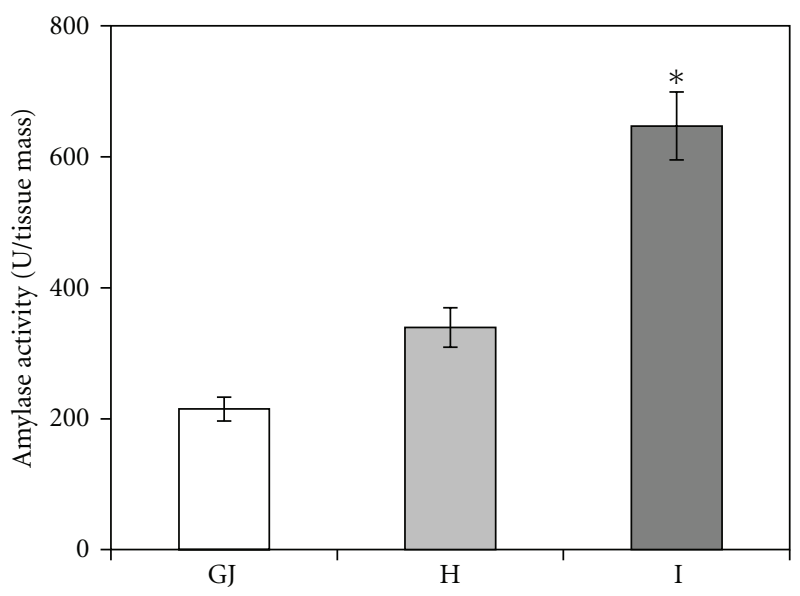

(a)

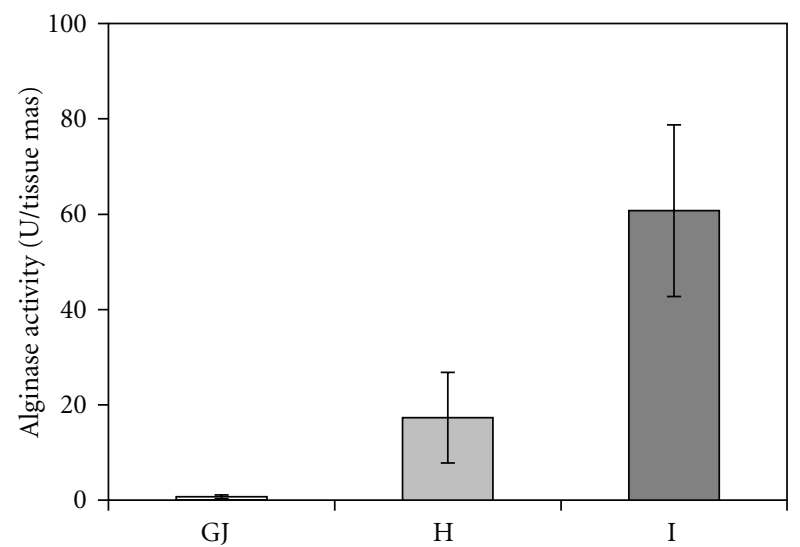

(c)

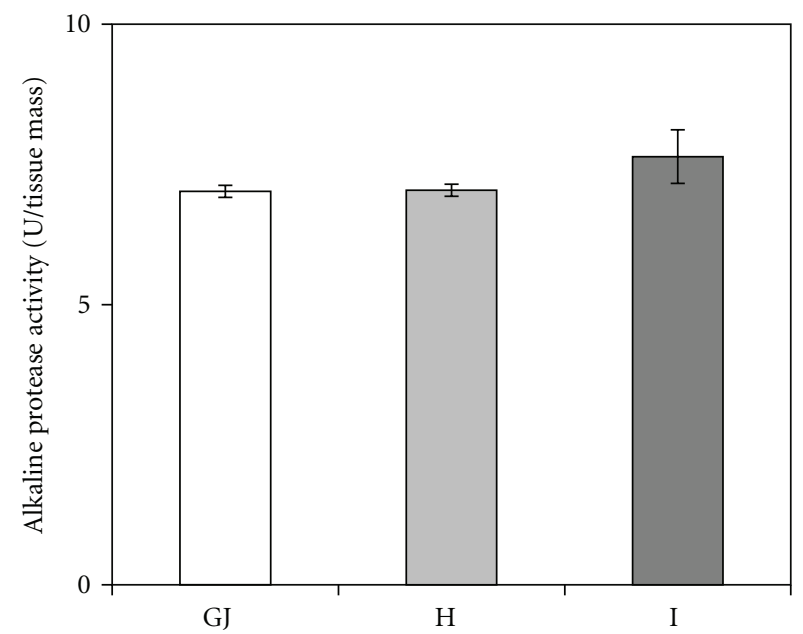

(e)

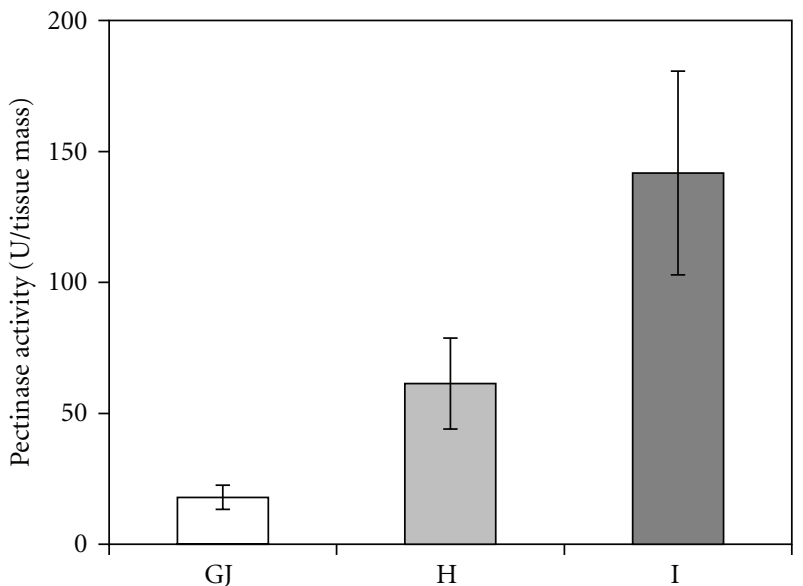

(b)

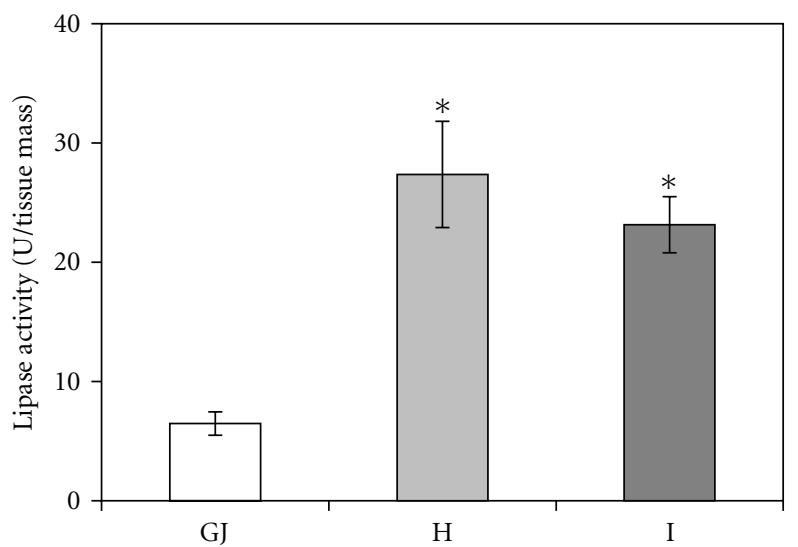

(d)

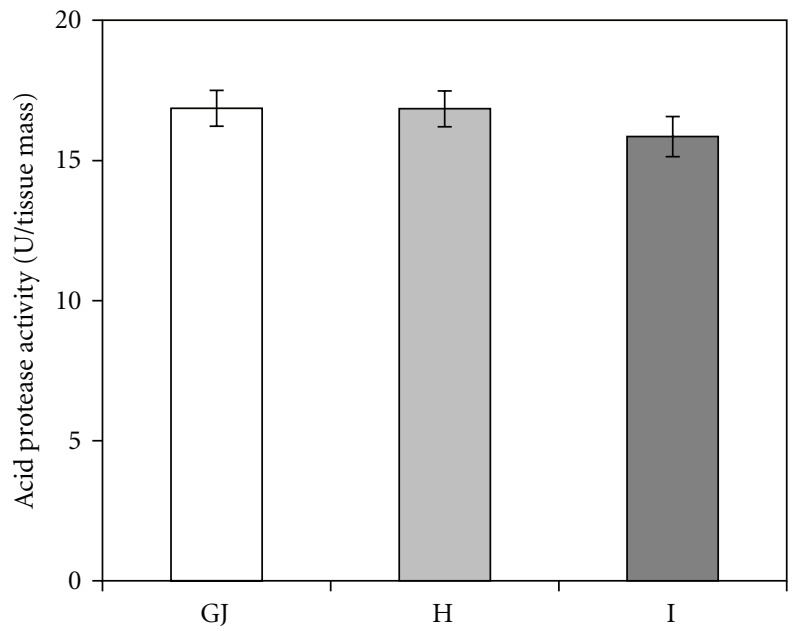

(f)

FIGURE 4: Enzymatic activities of amylase, pectinase, alginase, lipase, alkaline protease, and acid protease (U/tissue mass) in the gastric juice (GJ), hepatopancreas (H), and intestine (I) of Cherax albidus. Data represent means \pm SEM. For each group, $n=10$. Asterisks represent statistically significant differences $(P<.05)$ along the digestive tract. $(F(2,27)=4.13$ and $F(2,27)=3.85$ for amylase and lipase, resp. $)$. 


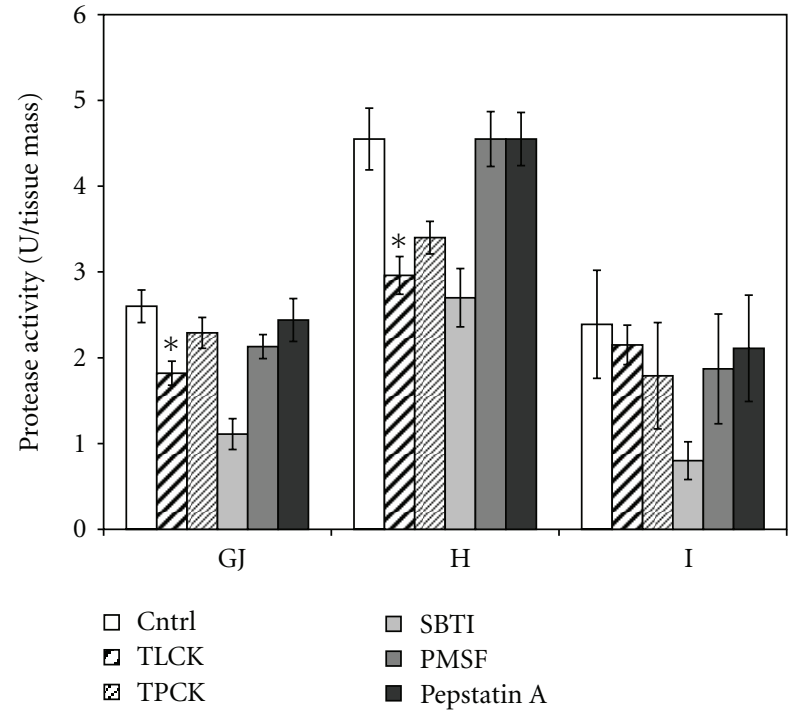

Figure 5: Effect of specific inhibitors on alkaline protease activity in the gastric juice $(\mathrm{GJ})$, hepatopancreas $(\mathrm{H})$, and intestine (I) of Cherax albidus. The percentage of inhibition was calculated considering the total activity (without inhibitor). Data represent means \pm SEM. For each group, $n=10$. Asterisks represent statistically significant differences $(P<.05)$ along the digestive tract. $(F(2.27)=3.98$ for TLCK inhibition $)$.

$[24,25]$, amylase activity is the highest among carbohydratases. Lipase activity values found in our study were comparable to those reported by López-López et al. [12] in the hepatopancreas of juveniles of Cherax quadricarinatus. Although it is unclear how lipase contributes to digestibility in crustaceans, it seems strongly correlated with diet [13]. However, López-López et al. [12] report that lipase activity was not significantly different among dietary treatments in Cherax quadricarinatus, while Pavasovic et al. [13] reported a higher lipase activity in the hepatopancreas of Cherax quadricarinatus fed plant-based diets in comparison to animalbased diets. In our study, lipase activity was significantly higher in the hepatopancreas and intestine than in gastric juices as reported in the spiny lobster Panulirus argus [21]. This is likely due to the fact that lipid digestion does not start in the gastric chamber as it does in the case of carbohydrate and protein hydrolysis [21].

Protease activity and characterization have been well documented for marine crustaceans, while information about freshwater crayfish is still poor. We found alkaline protease activity in Cherax albidus higher than the one reported in Macrobrachium australiense [2] and in Cherax quadricarinatus juveniles [12]. Since we carried out our experiments on juvenile crayfish, lighter than those employed by López-López [12], such a discrepancy could be due to age. Indeed, Figueiredo and Anderson [26] demonstrated that protease activity in the hepatopancreas of Cherax quadricarinatus declines with age. In this study, we have also characterized the class of alkaline proteases and identified serine proteases (trypsin-like and chymotrypsin-like enzymes) as the most active enzymes along the digestive tract of Cherax albidus, a common feature with other decapods $[4,20,23]$. In particular, we employed two different serineprotease inhibitors, SBTI and PMSF. SBTI was more effective than PMSF to inhibit serine-protease activities. Since SBTI is more specific for trypsin-like enzymes, probably trypsinlike enzymes represent the main serine proteases [23]. We also determined acid protease activities along the digestive tract of Cherax albidus. The activity of acid proteases has never been reported in freshwater crayfish. Using pepstatin A, we identified aspartic protease activity in the gastric juice, hepatopancreas and intestine. The presence of aspartic proteases in crustaceans was challenged for a long time until Navarrete del Toro et al. [20] identified aspartic proteases in the digestive tract of several decapods. Data reporting crustacean protease activity are in conflict. In Cherax quadricarinatus, protease activity has been reported to be influenced by dietary protein levels [14] and types of ingredients $[12,13]$. In contrast, in the white shrimp Penaeus vannamei dietary protein level did not influence the total protease activity although modulation of trypsinand chymotrypsin-like activities has been documented [27]. Moreover, no significant difference was observed in protease activity of Litopenaeus vannamei [28] and Scylla serrata subjected to different dietary treatments [22]. We found that in Cherax albidus protease activities did not change along the digestive tract. According to our results, it seems that Cherax albidus preferably hydrolyzes carbohydrates, as also indicated by $\mathrm{C} / \mathrm{P}$ and $\mathrm{C} / \mathrm{L}$ ratios that were considerably higher than those reported for Cherax quadricarinatus [13] fed a similar percentage of proteins used in our study.

The electrophoretic pattern of digestive enzymes of Cherax albidus shows enzyme polymorphism along the digestive tract. We found four amylase isoforms $(38,44,49$ and $55 \mathrm{kDa})$ in the gastric juice, hepatopancreas and intestine of Cherax albidus in agreement with Perera et al. [21] that reported four amylase isoforms, with similar mw, in the hepatopancreas of spiny lobster.

In the literature, there are several studies reporting crustaceans lipase with variable MW $[8,29-31]$. This is likely due to the differences in substrates employed, which are not always specific for lipase. In this study, we used $\alpha$-naphtyl caprylate, an octanoate fatty acid as substrate, considered specific for lipase [32]. We found several lipase isoforms with MW comprised between 57 and $118 \mathrm{kDa}$ along the digestive tract.

Five active bands with protease activity have been identified in Cherax albidus (present data). According to inhibition assays, they were mainly serine proteases. In particular, two isoforms, (18 and $19 \mathrm{kDa})$ behaved like trypsin. There are no data about freshwater crayfish protease characterization in the literature, but our results are consistent with those of other marine shrimps that have trypsin-like enzymes with molecular weight ranging between 10 and $22 \mathrm{kDa}[19,21$, 23]. The active bands of 25 and $27 \mathrm{kDa}$ reported by us behaved as serine proteases, and, although they were not inhibited by specific inhibitors (TLCK and TPCK), they might be chymotrypsin-like enzymes as reported in marine shrimps $[19,21,23]$. Finally, the $29 \mathrm{kDa}$ isoform cannot be 


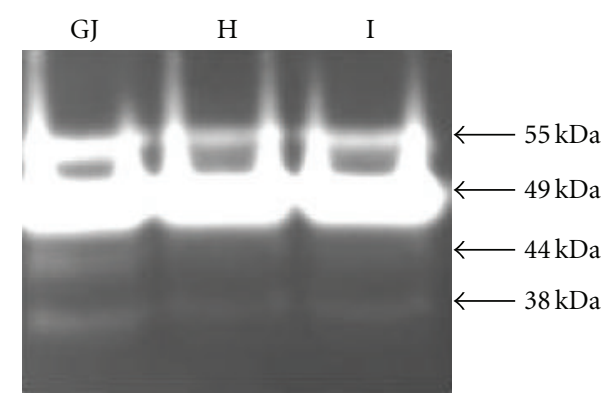

(a)

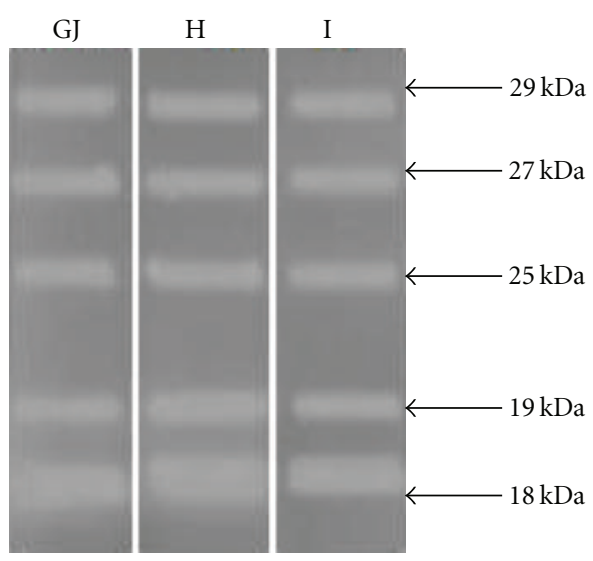

(c)

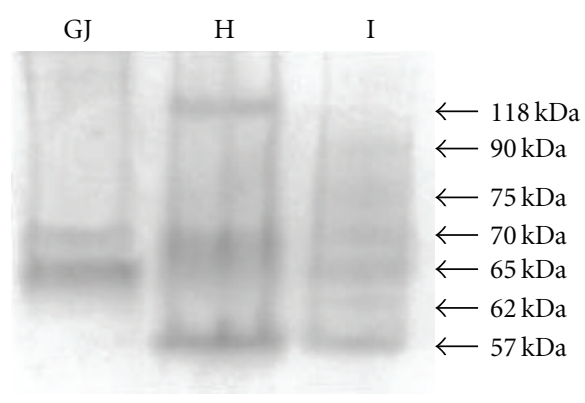

(b)

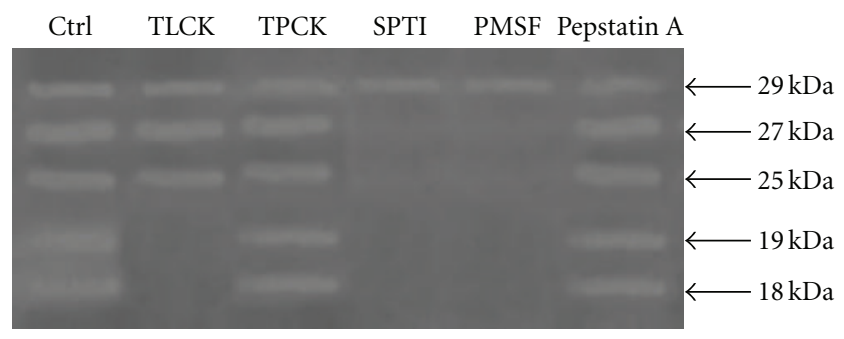

(d)

FIGURE 6: (a) Substrate SDS-PAGE showing amylolytic activity bands of juvenile Cherax albidus. (b) Substrate native-PAGE showing lipase activity bands. (c) Substrate SDS-PAGE showing protease activity bands. (d) Substrate SDS-PAGE showing protease activity bands (Ctrl) and their inhibition by specific inhibitors for trypsin (TLCK), chymotrypsin (TPCK), serine proteases (SBTI and PMSF), and aspartic proteases (pepstatin A). Each zymogram analysis was performed three times on gastric juice (GJ), hepatopancreas (H), and intestine (I) of three independent samples $(n=3)$. MW standards are reported on the right. The arrows indicate the active bands and their correspondent apparent molecular masses.

classified, because none of the inhibitors were able to reduce its activity.

In conclusion, we highlighted the broad suite of digestive enzymes present in the digestive tract of juvenile freshwater crayfish Cherax albidus. This species is capable of hydrolyzing a wide range of nutrients although there is a clear indication that carbohydrates are the substrate preferred.

\section{Acknowledgment}

This research was supported by a grant to M. Paolucci by the Sicily Regional Authority (Assessorato Agricoltura e Foreste).

\section{References}

[1] H. J. Ceccaldi, "Anatomy and physiology of the digestive system," in Crustacean Nutrition, L. R. D'Abramo, D. E. Conklin, and D. M. Akiyama, Eds., pp. 261-291, The World Aquaculture Society, Baton Rouge, La, USA, 1997.

[2] M. S. R. B. Figueiredo and A. J. Anderson, "Digestive enzyme spectra in crustacean decapods (Paleomonidae, Portunidae and Penaeidae) feeding in the natural habitat," Aquaculture Research, vol. 40, no. 3, pp. 282-291, 2009.
[3] S. J. Beatty, "The diet and trophic positions of translocated, sympatric populations of Cherax destructor and Cherax cainii in the Hutt River, Western Australia: evidence of resource overlap," Marine and Freshwater Research, vol. 57, no. 8, pp. 825-835, 2006.

[4] S. M. Linton, B. J. Allardyce, W. Hagen, P. Wencke, and R. Saborowski, "Food utilisation and digestive ability of aquatic and semi-terrestrial crayfishes, Cherax destructor and Engaeus sericatus (Astacidae, Parastacidae)," Journal of Comparative Physiology B, vol. 179, no. 4, pp. 493-507, 2009.

[5] A. Campaña-Torres, L. R. Martinez-Cordova, H. VillarrealColmenares, and R. Civera-Cerecedo, "In vivo dry matter and protein digestibility of three plant-derived and four animalderived feedstuffs and diets for juvenile Australian redclaw, Cherax quadricarinatus," Aquaculture, vol. 250, no. 3-4, pp. 748-754, 2005.

[6] A. Campaña-Torres, L. R. Martínez-Córdova, H. VillarrealColmenares, and R. Civera-Cerecedo, "Carbohydrate and lipid digestibility of animal and vegetal ingredients and diets for juvenile Australian redclaw crayfish, Cherax quadricarinatus," Aquaculture Nutrition, vol. 12, no. 2, pp. 103-109, 2006.

[7] M. S. R. B. Figueiredo, J. A. Kricker, and A. J. Anderson, "Digestive enzyme activities in the alimentary tract of redclaw crayfish, Cherax quadricarinatus (decapoda: Parastacidae)," Journal of Crustacean Biology, vol. 21, no. 2, pp. 334-344, 2001. 
[8] S. López-López, H. Nolasco, and F. Vega-Villasante, "Characterization of digestive gland esterase-lipase activity of juvenile redclaw crayfish Cherax quadricarinatus," Comparative Biochemistry and Physiology Part B, vol. 135, no. 2, pp. 337-347, 2003.

[9] A. C. Crawford, N. R. Richardson, and P. B. Mather, "A comparative study of cellulase and xylanase activity in freshwater crayfish and marine prawns," Aquaculture Research, vol. 36, no. 6, pp. 586-592, 2005.

[10] D. B. Rouse, "Australian crayfish culture in the Americas," Journal of Shellfish Research, vol. 14, no. 2, pp. 569-572, 1995.

[11] H. Ackefors and O. V. Lindqvist, "Cultivation of freshwater crayfishes in Europe," in Freshwater Crayfish Aquaculture in North America, Europe and Australia, J. V. Huner, Ed., p. 312, Hasworth Press, New York, NY, USA, 1994.

[12] S. López-López, H. Nolasco, H. Villarreal-Colmenares, and R. Civera-Cereced, "Digestive enzyme response to supplemental ingredients in practical diets for juvenile freshwater crayfish Cherax quadricarinatus," Aquaculture Nutrition, vol. 11, no. 2, pp. 79-85, 2005.

[13] A. Pavasovic, A. J. Anderson, P. B. Mather, and N. A. Richardson, "Effect of a variety of animal, plant and single cell-based feed ingredients on diet digestibility and digestive enzyme activity in redclaw crayfish, Cherax quadricarinatus (Von Martens 1868)," Aquaculture, vol. 272, no. 1-4, pp. 564572, 2007.

[14] A. Pavasovic, A. J. Anderson, P. B. Mather, and N. A. Richardson, "Influence of dietary protein on digestive enzyme activity, growth and tail muscle composition in redclaw crayfish, Cherax quadricarinatus (von Martens)," Aquaculture Research, vol. 38, no. 6, pp. 644-652, 2007.

[15] A. Pavasovic, N. A. Richardson, P. B. Mather, and A. J. Anderson, "Influence of insoluble dietary cellulose on digestive enzyme activity, feed digestibility and survival in the red claw crayfish, Cherax quadricarinatus (von Martens)," Aquaculture Research, vol. 37, no. 1, pp. 25-32, 2006.

[16] P. L. Jones, S. S. De Silva, and B. D. Mitchell, "Effect of dietary protein content on growth performance, feed utilization and carcass composition in the Australian freshwater crayfish, Cherax albidus Clark and Cherax destructor Clark (Decapoda, Parastacidae)," Aquaculture Nutrition, vol. 2, no. 3, pp. 141150, 1996.

[17] M. P. Hernandez, D. B. Rouse, and M. A. Olvera, "Effect of dietary protein-lipid ratios on survival and growth of Australian crayfish (Cherax quadricarinatus) hatchlings and juveniles," Freshwater Crayfish, vol. 13, pp. 97-106, 2001.

[18] "AOAC Official Method International," 2007, http://www.aoac .org.

[19] A. V. Fernández Gimenez, F. L. García-Carreño, M. A. Navarrete del Toro, and J. L. Fenucci, "Digestive proteinases of red shrimp Pleoticus muelleri (Decapoda, Penaeoidea): partial characterization and relationship with molting," Comparative Biochemistry and Physiology Part B, vol. 130, no. 3, pp. 331338, 2001.

[20] M. A. Navarrete del Toro, F. L. García-Carreño, M. DíazLópez, L. Celis-Guerrero, and R. Saborowski, "Aspartic proteinases in the digestive tract of marine decapod crustaceans," Journal of Experimental Zoology Part A, vol. 305 A, no. 8, pp. 645-654, 2006.

[21] E. Perera, F. J. Moyano, M. Díaz et al., "Polymorphism and partial characterization of digestive enzymes in the spiny lobster Panulirus argus," Comparative Biochemistry and Physiology Part B, vol. 150, no. 3, pp. 247-254, 2008.
[22] M. Pavasovic, N. A. Richardson, A. J. Anderson, D. Mann, and P. B. Mather, "Effect of $\mathrm{pH}$, temperature and diet on digestive enzyme profiles in the mud crab, Scylla serrata," Aquaculture, vol. 242, no. 1-4, pp. 641-654, 2004.

[23] L. E. Celis-Guerrero, F. L. García-Carreño, and M. A. Navarrete del Toro, "Characterization of proteases in the digestive system of spiny lobster (Panulirus interruptus)," Marine Biotechnology, vol. 6, no. 3, pp. 262-269, 2004.

[24] G. Gaxiola, G. Cuzon, T. García et al., "Factorial effects of salinity, dietary carbohydrate and moult cycle on digestive carbohydrases and hexokinases in Litopenaeus vannamei (Boone, 1931)," Comparative Biochemistry and Physiology Part A, vol. 140, no. 1, pp. 29-39, 2005.

[25] D. Johnston and J. Freeman, "Dietary preference and digestive enzyme activities as indicators of trophic resource utilization by six species of crab," The Biological Bulletin, vol. 208, no. 1, pp. 36-46, 2005.

[26] M. S. R. B. Figueiredo and A. J. Anderson, "Ontogenetic changes in digestive proteases and carbohydrases from the Australian freshwater crayfish, redclaw Cherax quadricarinatus (Crustacea, Decapoda, Parastacidae)," Aquaculture Research, vol. 34, no. 13, pp. 1235-1239, 2003.

[27] A. Muhlia-Almazán, F. L. García-Carreño, J. A. Sánchez-Paz, G. Yepiz-Plascencia, and A. B. Peregrino-Uriarte, "Effects of dietary protein on the activity and mRNA level of trypsin in the midgut gland of the white shrimp Penaeus vannamei," Comparative Biochemistry and Physiology Part B, vol. 135, no. 2, pp. 373-383, 2003.

[28] M. E. Rivas-Vega, E. Goytortúa-Bores, J. M. Ezquerra-Brauer et al., "Nutritional value of cowpea (Vigna unguiculata L. Walp) meals as ingredients in diets for Pacific white shrimp (Litopenaeus vannamei Boone)," Food Chemistry, vol. 97, no. 1, pp. 41-49, 2006.

[29] S. Cherif, A. Fendri, N. Miled, H. Trabelsi, H. Mejdoub, and Y. Gargouri, "Crab digestive lipase acting at high temperature: purification and biochemical characterization," Biochimie, vol. 89, no. 8, pp. 1012-1018, 2007.

[30] N. Iijima, S. Tanaka, and Y. Ota, "Purification and characterization of bile salt-activated lipase from the hepatopancreas of red sea bream, Pagrus major," Fish Physiology and Biochemistry, vol. 18, no. 1, pp. 59-69, 1998.

[31] C. Rivera-Perez, F. L. García-Carreño, and R. Saborowski, "Purification and biochemical characterization of digestive lipase in whiteleg shrimp," Marine Biotechnology, vol. 13, no. 2, pp. 284-295, 2010.

[32] D. Gilhan and R. Lehner, "Techniques to measure lipase and esterase activity in vitro," Methods, vol. 36, no. 2, pp. 139-147, 2005. 

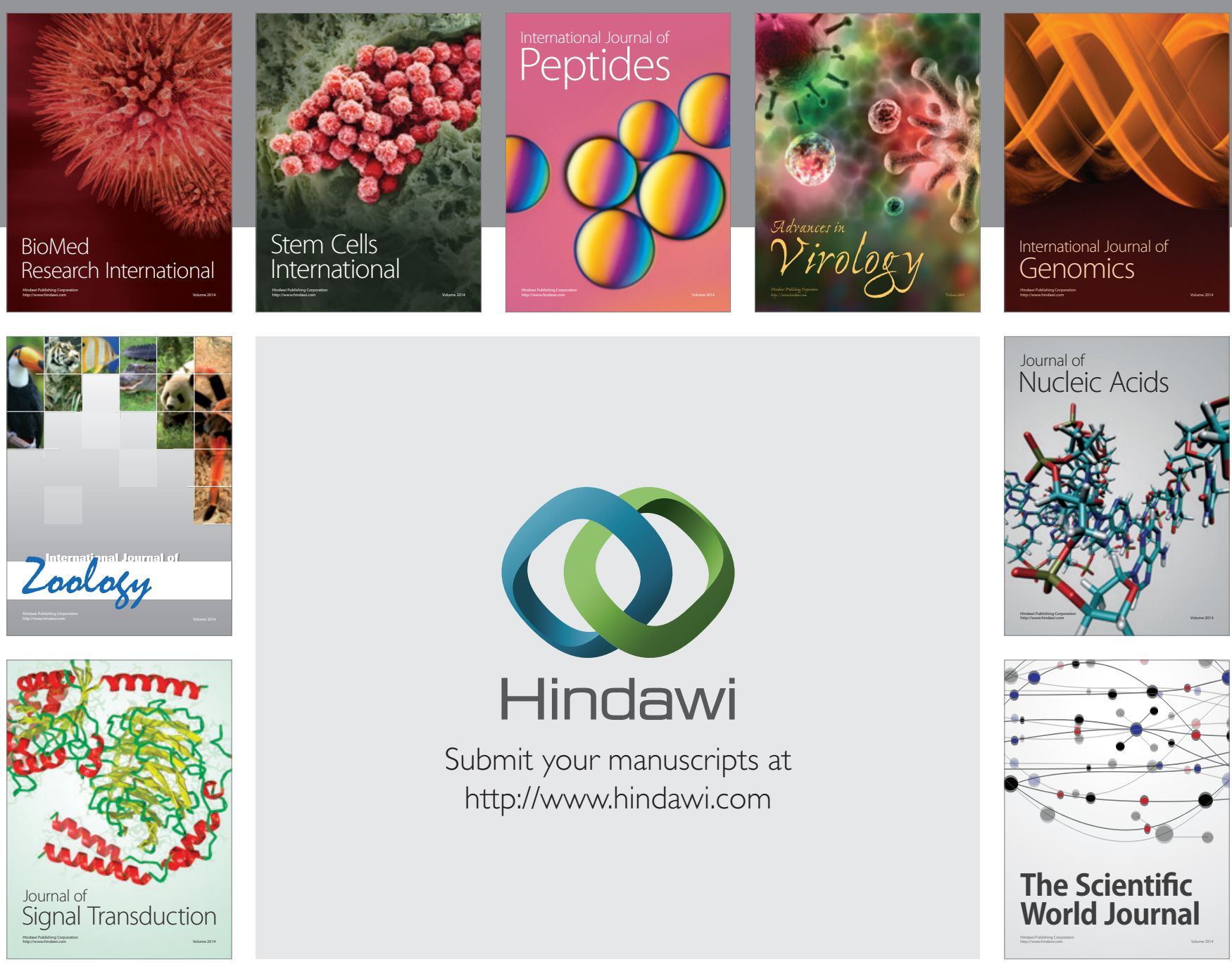

Submit your manuscripts at

http://www.hindawi.com
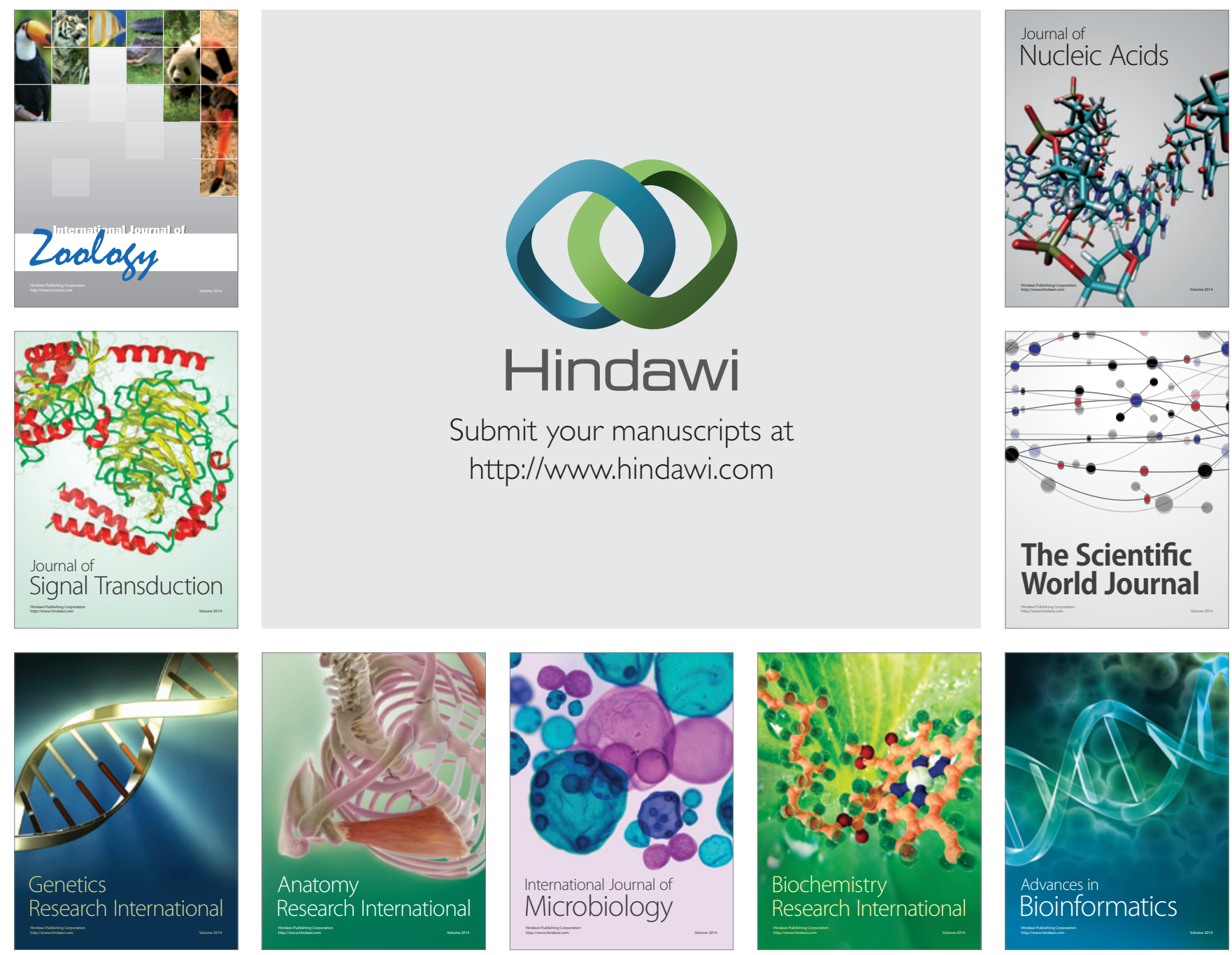

The Scientific World Journal
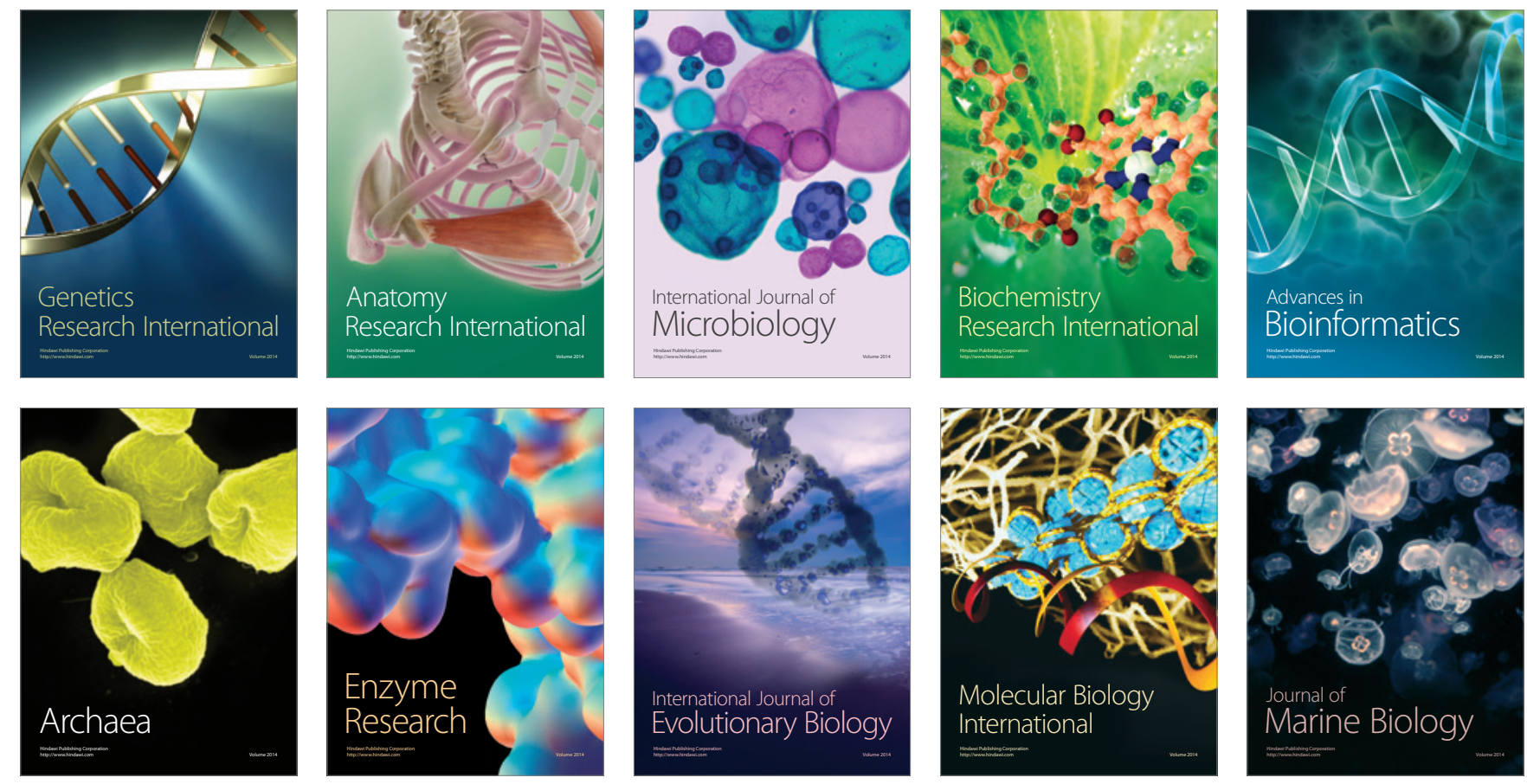